\title{
Yesterday, Today and Tomorrow: Post-Acquisition Evidence and Probable Anticompetitive Effects
}

\author{
Paul S. Ferber*
}

\begin{abstract}
Because Clayton Act cases often reach court only long after a challenged merger has occurred, a frequent issue is the proper weight to be given post-acquisition evidence of the merged firm's conduct or competitors' response. Unsatisfied by the positions taken by the Federal Trade Commission, various district courts, and the United States Supreme Court, Paul Ferber suggests a new approach to the use of post-acquisition evidence which is both comprehensive and flexible. The major portion of the article is dedicated to an application of the approach to various types of horizontal, vertical and conglomerate mergers.
\end{abstract}

In the unceasing quest for a winning defense in a section 7 action, defendants frequently have referred to post-acquisition evidence as proof of a merger's validity. ${ }^{1}$ Several district courts ${ }^{2}$ and courts of appeals ${ }^{3}$ have found such evidence persuasive, but the Supreme Court invariably has reversed. ${ }^{4}$ Despite the substantial lack of success to date, there are situations in which certain types of post-acquisition evidence should be accorded substantial weight in favor of a inerger's validity.

* J.D. 1966, New York University. Formerly an attorney in the Antitrust Division, Department of Justice. Member of the California and New York Bars.

1. Clayton Act $\S 7,15$ U.S.C. $\S 18$ (1964), provides in part that mergers are unlawful if they [tend] "substantially to lessen competition or tend to create a monopoly." This statute proscribes mergers which probably will have anti-competitive effects.

2. United States v. Von's Grocery Co., 233 F. Supp. 976 (S.D. Cal. 1964); United States v. Continental Can Co., 217 F. Supp. 761 (S.D.N.Y. 1963); United States v. Aluminum Company of America, 214 F. Supp. 501 (N.D.N.Y. 1963).

3. Proctor \& Gamble Co. v. FTC, 358 F.2d 74 (6th Cir. 1966); Consolidated Foods Corp. v. FTC, 329 F.2d 623 (7th Cir. 1964).

4. FTC v. Proctor \& Gamble Co., 386 U.S. 568 (1967); United States v. Von's Grocery Co., 384 U.S. 270 (1966); FTC v. Consolidated Foods Corp., 380 U.S. 592 (1965); United States v. Continental Can Co., 378 U.S. 441 (1964); United States v. Aluminum Company of America, 377 U.S. 271 (1964).

5. Several commentators have concluded that the Supreme Court is likely to hold unlawful any merger the enforcement agencies choose to attack, Cook, Merger Law and Big Business: A Look Ahead, 40 N.Y.U.L. REv. 710, 712 (1965); Pitofsky \& Millstem, Trade Regulation, 1965 ANNUAL SURv. AM. L., 103, 110. After the 
The test of illegality under section 7 of the Clayton Act is prospective. Proof of actual anticompetitive effects is unnecessary. The thrust of the inquiry is the probability of anticompetitive effects evolving as a result of the merger at some time in the future. This approach permits the enforcement agencies to file a complaint challenging a merger and seeking preliminary and permanent mjunctive relief even before the merger has been consummated.

Nevertheless, post-acquisition evidence has been and is likely to remain available. First, the number of mergers consummated each year is great and is increasing yearly. ${ }^{6}$ The enforcement agencies' resources are relatively limited. ${ }^{7}$ Consequently, mergers which the agencies consider sufficiently important to challenge may be consummated before the agencies are prepared to act or even become aware of the merger. Second, a section 7 action may be brought at any time the proscribed effects appear probable, whether five, ten, or thirty years after the inerger is consummated. 8 Third, a section 7 case is as susceptible to protracted proceedings as other types of antitrust cases. The delay between the filing of the complaint and the trial may be sub-

Supreme Court decision in Consolidated Foods, an unnamed Federal Trade Commissioner was quoted as stating, "I don't see how we can lose any merger case now." BusnNess WeEk, July 2, 1966, at 34.

Such prognosis must be tempered by the ultimate success of the Penn-Olin joint venture, although it was sustained by virtue of an equally divided court. United States v. Penn-Olin Chem. Co., 389 U.S. 308 (1967).

6. Despite an almost unprecedented streak of success by the Department of Justice in challenging mergers, there were 4,462 mergers in 1968, up 50 percent from the previous high of 2,975 in 1967. Los Angeles Times, January 7, 1969, $\$ \mathrm{III}$, at 9, col. 5 (city ed.).

7. Between 1950 and 1965 , the enforcement agencies filed 143 section 7 complaints although the rate of recorded mergers was about 1,200 per year. B. Bock, MERGERS AND MARKETS 9 (4th ed. 1965). In determining which inergers to challenge, the agencies may well consider factors which the Court would find unpersuasive as a defense.

Then Attorney General Katzenbach indicated that only about one of 100 mergers are challenged in legal proceedings. Reınarks before the Business Conncil, Hot Springs, Virginia, May 8, 1965, in 5 Trade REg. Rep. If 50114.

8. Umited States v. E.I. du Pont de Nemours \& Co., 353 U.S. 586 (1957). Du Pont acquired 23 pereent of General Motors stock between 1917 and 1919. The Government filed its complaint in 1949. The Supreme Court concluded: "To accoinplish the congressional aim, the Government may proceed at any time that an acquisition may be said with reasonable probability to contain a threat that it may lead to a restraint of commeree or tend to create a monopoly of a line of commerce." Id. at 597.

Frequently, the complaint is not filed for more than a year after the merger. See United States v. National Steel Corp., 251 F. Supp. 693 (S.D. Tex. 1965) (13 months); United States v. Aluminum Co. of America, 377 U.S. 271 (1964) (12 months). The F.T.C. has delayed for longer periods. See EKCO Products Co., [1963-1965 Transfer Binder] TRADE REG. REP. ๆ 16,879 (FTC 1964) (two years for one acquisition and four years for a second); Consolidated Foods Corp., 62 F.T.C. 929 (1963) (seven years). The F.T.C. recently filed a complaint against a 1965 merger. Proctor \& Gámble Co., No. C-1169 (F.T.C. Feb. 9, 1967). 
stantial. ${ }^{9}$ Therefore, even where the complaint is filed before the firms physically merge, post-acquisition evidence may be available by the time the case is tried. Judicial reluctance to issue a preliminary mjunction increases the likelihood that post-acquisition evidence will be available. $^{10}$

The purpose of this Article is to establish that certain types of postacquisition evidence should be accorded substantial weight in favor of a merger's validity. Part I surveys and analyzes current Umited States Supreme Court, federal district court and Federal Trade Commission approaches to the use of post-acquisition evidence. Part II presents the author's suggestions for an improved approach to the problemone which recognizes the probative value of certain post-acquisition evidence, while limiting the potential abuses in its use-and illustrates the operation of this recommended approach in the contexts of horizontal, vertical, and conglomerate mergers.

I

\section{CURRENT APPROACHES TO THE USE OF POST-ACQUISITION EVIDENCE}

\section{A. Supreme Court Decisions}

The Supreme Court's section 7 decisions contained little discussion of the propriety of defensive use of post-acquisition evidence until Federal Trade Commission v. Consolidated Foods Corporation. ${ }^{11}$ In prior

9. It is not unusual for three or four years to elapse between the filing of the complaint and the decision. See, e.g., United States v. Von's Grocery Co., 233 F. Supp. 976 (S.D. Cal. 1964) (complaint filed in 1960). In Proctor \& Gamble Co., 63 F.T.C. 1465 (1963), three years separated the filing of the conplaint and the hearing examiner's initial decision. When the Commission reviewed the decision almost one year later, it decided to remand the case to permit the examiner to take evidence on post-acquisition changes in the market. 58 F.T.C. 1203 (1961). Not until the Supreme Conrt's decision in 1967, ten years after the acquisitiou, was the legality of Proctor's acquisition of Clorox finally established. FTC v. Proctor \& Gamble Co., 386 U.S. 568 (1967).

10. See Flynn, A Survey of Injunctive Relief Under State and Federal Antitrust Laws, 1967 Utah L. Rev. 344, 356-57 (1967). But see Note, Preliminary Injunctions and the Enforcement of Section 7 of the Clayton Act, 40 N.Y.U.L. REv. 771, 772 (1965).

Of late, district courts have been somewhat more willing to enjoin at least the physical merging with consequent disappearance of one independent entity. See United States v. Atlantic Richfield Co., 297 F. Supp. 1060 (S.D. N.Y. 1969); United States v. Wilson Sporting Goods Co., 288 F. Supp. 543 (N.D. Ill. 1968). But see United States v. Tidewater Marine Service, 284 F. Supp. 324 (E.D. La. 1968).

11. 380 U.S. 592 (1965). Even the majority opinion in Consolidated Foods left doubt as to whether post-acquisition evidence might be persuasive of a merger's validity in an unusual case. "The Court of Appeals was not in error in considering the post-acquisition evidence in this case. See [United States v. E. I. du Pont de Nemours \& Co., 353 U.S. 586, 597 et seq. (1957)]. But we think it gave it too much weight." 380 U.S. at 598. 
decisions, the Court either found the post-acquisition evidence condemning rather than exonerating, ${ }^{12}$ or it found the particular evidence unpersuasive on some practical basis. ${ }^{13}$

Consolidated Foods Corporation, a distributor of packaged food items, among other things, acquired Gentry Incorporated, a manufacturer of deliydrated onion and garlic, in 1956. Gentry's products were used extensively as preservatives in packaged foods inanufactured by food processors who relied on Consolidated as a source of distribution and on Gentry and Gentry's only inajor competitor to obtain its requirements of dehydrated onion and garlic. The Federal Trade Commission contended that the merger enabled Consolidated to use its position as a leading distributor of food products to retailers to coerce or induce manufacturers to purchase their requirements of dehydrated onion and garhic from Gentry.

12. The Government's complaint in United States v. E.I. du Pont de Nemours \& Co., 353 U.S. 586 (1957), challenged DuPont's acquisition of 23 percent of General Motors' coinmon stock 30 years after the acquisition and relied heavily on post-acquisition evidence. DuPont argued that it had not employed its voting power to coerce or induce G.M. executives to purchase DuPont products. Both the Government and the defendant filled the record with post-acquisition statistics attempting to prove, alternatively, foreclosure and lack of foreclosure.

By limiting the relevant market in which to gauge the competitive impact, the Supreine Court made irrelevant the defendant's post-acquisition evidence of lack of foreclosure as to a wide range of products, and referred to post-acquisition evidence showing that DuPont had becoine G.M.'s leading supplier on a few products. In any event, the Court observed that "[S]ection [7 of the Clayton Act] is violated whether or not actual restraints or monopolies, or the substantial lessening of competition, have occurred or are intended." Id. at 589.

13. In Brown Shoe Co. v. United States, 370 U.S. 294 (1962), the defendant argued that the fact that the market remained fragmented and competitive after the merger indicated that section 7 was not violated. The majority opinion rejected the argument, concluding that "remaining vigor cannot immunize a merger if the trend in that industry is toward oligopoly." Id. at 333. The opinion has been construed as authorizing a fairly broad economic inquiry labeled alternatively a "rule of reason," Bock, The Relativity of Economic Evidence in Merger Cases-Emerging Decisions Force the Issue, 63 Mrch. L. REv. 1355, 1357 (1965), or as a "modified rule of reason," Blackford, Vertical Acquisition and Section 7 of the Clayton Act, 17 W. REs. L. REV. 102, 118 (1965).

In United States v. Philadelphia Nat'l Bank, 374 U.S. 321 (1963), the Court rejeeted testimony by bank officers that competition in the Philadelphia area would remain vigorous despite the merger on the grounds that: "This lay evidence on so complex an econornic-legal problem as the substantiality of the effect of this merger upon competition was entitled to little weight, in view of the witness' failure to give concrete reasons for their conclusions." Id. at 367.

In United States v. Continental Can Co., 378 U.S. 441 (1964), the defendant, a leading metal container manufacturer, argued that since it had operated the acquired firm, a glass container manufacturer, as an independent subsidiary, it would not interfere with the developing competition between its glass and metal container divisions. The Court noted that the complaint was filed before the merger was consummated, and therefore rejected the defendant's argument on the ground that the failure to restrain the acquired glass container subsidiary probably resulted from the pending section 7 action. Id. at 463. 
The court of appeals relied heavily on ten years of post-acquisition evidence to reverse the Commission's finding that Consolidated's acquisition of Gentry violated section $7 .^{14}$ It found that any alleged power which the merger gave Consolidated to increase Gentry's sales by the use of reciprocity had failed to materialize. Writing for the majority in reversing, Justice Douglas concluded that the court of appeals had not erred in considering post-acquisition evidence but had erred in relying on it too heavily. ${ }^{15}$ Despite a few vague remarks about the merits of post-acquisition evidence in general, the opinion rejects placing great reliance on post-acquisition evidence on the practical ground that the evidence showed concrete efforts by Consolidated to obtain patronage for Gentry through use of Consolidated's purchasing power. ${ }^{16}$

Justice Douglas raised two intelligible objections to according postacquisition evidence conclusive weight. First, it would imduce merging firms to refrain from implementing the merger's advantages to establish a favorable post-acquisition record and thereby might result in judicial approval of a merger which may have the proscribed effects some time thereafter. Second, post-acquisition evidence alone does not permit a determination of whether coinpetition would have been more vigorous liad the acquisition not occurred. If competition would have been more vigorous, the fact that post-acquisition evidence establishes some increase in competition does not validate an acquisition. ${ }^{17}$

In a concurring opmion, Justice Harlan indicated a willingness to rely on post-acquisition evidence in appropriate circumstances. $\mathrm{He}$ concluded, lowever, that the post-acquisition evidence did not reflect the full impact of Consolidated's reciprocity power. Therefore, the absence of significant anticompetitive effects did not exclude the probability that Consolidated could implement the unexercised power to the detriment of the competitive process at some time in the future..$^{18}$

In a second concurring opinion, Justice Stewart disagreed with the majority's assessment of the weight to be accorded post-acquisition evidence on the ground that the best evidence available in each case should be accorded the greatest weight. Post-acquisition evidence generally is the best evidence on which to determine whether the merger actually

14. Consolidated Foods Corp. v. FTC, 329 F.2d 623, 626 (7th Cir. 1964).

15. 380 U.S. at 598 .

16. One commentator noted the confusion which attended the emphasis on a factual analysis of the defendant's post-acquisition behavior by the majority and two concurring opinions. Donnely, The Supreme Court-The Federal Trade Commission and the Not-So Conglomerate Merger: An Analysis of Federal Trade Commission $v$. Consolidated Foods Corp., 43 U. DET. I.J. 35, 73 (1965).

17. 380 U.S. at 598. For example, the mere fact that the defendant's shares of the market decreased does not mean that the decrease would not have been greater in the absence of the advantages accruing from the merger.

18. Id. at 602 . 
distorted normal market forces. He argued that in the absence of such evidence the trier is faced with a "blank slate and untested speculation." 19 Indeed, he noted that post-acquisition evidence established that the merger had some procompetitive effects. ${ }^{20}$ In the seven year post-acquisition period, the two leading firms increased the quahty of their products. Nevertheless, he concluded that the court of appeals erred in ignoring post-acquisition evidence that established that many small firms had been induced to purcliase from Gentry as a result of Consolidated's use of reciprocity.

The following year, in United States $v$. Von's Grocery Company, ${ }^{21}$ the Court accepted the district court's findings that the relevant market remained highly competitive and was composed of numerous viable single-store and small chain-store operations in the three-year post-acquisition period. It concluded, however, that such evidence was not relevant to the ultimate issue on which the horizontal merger's validity turned. Section 7 was designed to prevent the evolution of noncompetitive market structures. The fact that this particular merger did not create an ohgopoly, as establislied by uncontroverted post-acquisition evidence, did not prove that the merger had not moved the market significantly closer toward that end. ${ }^{22}$

Dissenting, Justice Stewart, joined by Justice Harlan, reaffirmed his position regarding the use of post-acquisition evidence set out in his concurring opinion in Consolidated Foods. Relying on the "best evidence available," he examined the post-acquisition market and found the competitive structure unimpaired. Competition anong single-store groceries and chains was "vigorous to a fault."28 The substantial increase, both before and after the merger, in the number of chain stores was due largely to the success of, and resulting internal expansions by, many single-store operations. The market contained a large number of viable competitors, and price competition remained vigorous. Furtherinore, nine of the 20 largest chains had gone bankrupt since the merger. In Justice Stewarts words, "This substantial post-acquisition demise hardly comports with the Court's tacit portrayal of the inexorable march toward oligopoly."24

In FTC v. Proctor \& Gamble Company, ${ }^{25}$ the Supreme Court again reversed a lower court decision which upheld a merger relying in part on post-acquisition evidence. In reversing an F.T.C. finding that

\footnotetext{
19. Id. at 606 .

20. Id. at 605.

21. 384 U.S. 270 (1966).

22. Id. at 278.

23. Id. at 287.

24. Id. at 294.

25. 386 U.S. 568 (1967).
} 
Proctor's acquisition of Clorox violated section 7, the court of appeals relied on evidence that 200 small hiquid bleach producers had provided and seemed likely to continue to provide vigorous competition. ${ }^{26}$ The Supreme Court held that the court of appeals misapprehended the standards to be applied in reviewing the F.T.C. decision and in enforcing section 7. Requiring actual anticompetitive effects, as the court of appeals in effect had done, would thwart the congressional policy to halt anticompetitive developinents im their incipiency. ${ }^{2 \tau}$

In a concurring opinion, Justice Harlan supported the majority in deprecating post-acquisition evidence, contending that the difficulty in obtaining useful post-acquisition evidence outweighs its value. ${ }^{28}$ Yet, he indicated that a defendant in a conglomerate merger case should be permitted to prove that the merger would not result in the anticoinpetitive effects anticipated under oligopoly theory. He would have considered significant a showing that the unadvertised locally marketed bleaches placed a ceiling on the price a named brand such as Clorox could command through a set differential which was not significantly higher after than before the merger. The defendant would have to establish that its interpretation was "a more cogent explanation of the pattern of market behavior." ${ }^{29}$ In addition, he would permit the defendant to show that the merger produced real economies which made the merger pro-competitive. Notwithstanding Justice Harlan's initial rejection of post-acquisition evidence, logically the evidence would appear useful, if not indispensable, on these issues.

While it is difficult to dispute the often stated premise that section 7 may be violated without proof of actual restraint, this objection would be a proper response only to a defendant's rather unsophisticated attempt to rely solely on evidence that competition was actually not restrained after the merger. Obviously, standing alone, an absence of a reduction in the vigor of competition in the short run is equivocal. ${ }^{30}$

The argument that giving decisive consideration to post-acquisition evidence would induce merging firms to refrain from implementing a merger's advantages to estabhish a favorable record in anticipation of suit apphes only to limited types of post-acquisition evidence. Justice

26. Proctor \& Gamble Co. v. FTC, 358 F.2d 74, 80 (6th Cir. 1966).

27. 386 U.S. at 577.

28. Id. at 593 .

29. Id. at 596 .

30. The argument that in the absence of the merger or some anti-competitive practice, and its concomitant benefits, the market share might have decreased further or competition might have been more vigorons is far from new. Justice Frankfurter articulated it in Standard Oil Co. v. United States, 337 U.S. 293, 314 (1949), in rejecting the defendant's contention that despite the exclusive dealing contracts under attack, competition did not decrease and therefore the contracts had no significant anticompetitive impact. 
Douglas indicates the limits of this argument in the same opinion in which he makes the argument. ${ }^{31}$ Many anticompetitive effects result solely from a merger's alteration of the market structure and therefore are not subject to control by the merging firms. Indeed, the argument seems almost superfluous when it is remembered that section 7 is oriented toward structural rather than behavorial effects.

\section{B. Federal Trade Commission Decisions}

The Federal Trade Commission's position on post-acquisition evidence was unclear for several years. ${ }^{32}$ Presently, the Commission appears willing to accord post-acquisition evidence significant weight "only in the unusual case." ${ }^{33}$ In the majority of cases, the Commission considers post-acquisition evidence equivocal, subjective, or irrelevant to the basic inquiry under section 7 . To give it decisive weight would impair the effective enforcement of the statute.

Employing arguments reminiscent of Justice Douglas' in Consolidated Foods, the F.T.C. has rejected as equivocal a decrease in the merged firms' market share or continued vigorous competition after merger. $^{34}$ In the absence of the merger, the Commission has reasoned, the merging firms' share might have decreased further or competition imight have increased. ${ }^{35}$ The Commission has also argued that if merging firms know they may be able to exonerate their merger with postacquisition evidence, they will refram from implementing the power resulting from the merger. Should they obtain judicial approval, they will then be free to "unsheathe" their power and impair competition. ${ }^{80}$ This would totally subvert effective enforcement of section 7.

The focus of a section 7 action is the merger's impact on market structure. The Commission contends that relying on the absence of

31. FTC v. Consolidated Foods Corp., 380 U.S. 592, 597 (1965). One commentator interpreted Justice Douglas' opinion as coinpromising the positions taken by the F.T.C. and the court of appeals. See Dounely, supra note 16, at 36.

32. Compare Proctor \& Gamble Co., 58 F.T.C. 1203, 1207 (1961) with Proctor \& Gamble Co., 63 F.T.C. 1465, 1583 (1963). See also the multiple opinions in Union Carbide Corp., 59 F.T.C. 614 (1961).

33. Proctor \& Gamble Co., 63 F.T.C. 1465, 1559 (1963).

34. See Consolidated Foods Corp., 62 F.T.C. 929 (1962); Fruehauf Trailer Co., [1963-1965 Transfer Binder] Trade Reg. Rep. If 16,714 (FTC 1964). But see Kaiser Indus., [1963-1965 Transfer Binder] TRADE REg. REP. TI 16,529 (FTC 1963), where the Commission originally suspended proceedings to permit an economic survey of companies producing fabricated steel in the relevant market (Arizona) six years after Kaiser's acquisition of a leading fabricator. The Commission dismissed the complaint when the survey showed that the acquired company's share of the market decreased 75 percent between 1957 and 1962, while total market sales doubled. See also Dresser Indus., [1963-1965 Transfer Binder] TRADE REg. REP. II 16,513 (FTC 1963).

35. Proctor \& Gamble Co., 63 F.T.C. 1465 (1963).

36. $I d$. at 1584 . 
noncompetitive behavior would improperly shift the focus of section 7 proceedings froin a structural to a behavioral inquiry. ${ }^{37}$ Therefore, even if the defendant could establisl that the merger had not substantially lessened competition, sucli evidence would be irrelevant to the ultimate issue on which a merger's legality depends under section 7 .

The Commission lias argued that section 7 cannot be enforced effectively and adequate relief cannot be obtained if proceedings are protracted and records massive. ${ }^{38}$ Merging firms frequently consolidate their operations, and by the time the merger's validity is finally adjudicated, divestiture may be difficult or ineffectual. ${ }^{39}$ Permitting defendants to delay a final determination of a merger's legality by introducing post-acquisition evidence with little, if any, probative value, ignores the basic policy underlying section 7-to provide quick and effective relief -as well as the need to apply relatively simple tests of illegality wherever possible. ${ }^{40}$ Limiting the evidence to be introduced will shorten the proceedings and facilitate the issuance of effective orders.

Commissioner Kern has found unconvincing the arguments of the majority of the Commission, mucli as Justice Stewart has found unconvincing the arguments of the Supreme Court majority. Commissioner Kern has conceded that in limited market settings the Commission may rely on "a few simple compelling factors" in finding a violation. ${ }^{41}$ In most cases, lowever, the Commission's inquiry must include, and must rely lieavily upon, "the post-acquisition market realities." ${ }^{\text {2 }}$

37. Id. at 1583.

38. "If a market structure conducive to non-competitive practices or adverse competitive effects is shown to have been created or aggravated by a merger, it is surely immaterial that specific behavioral manifestations have not yet appeared." Proctor \& Gamble Co., [1963-1965 Transfer Binder] Trade Reg. Rep. $\llbracket 16,673$ at 21,574 (FTC 1963).

Mauy commeutators share the Commission's concern over unduly protracting section 7 cases and favor narrowing the basic issues and types of evidence which may be introduced in establishing requisite facts. C. KAYSEN \& D. TURNER, ANTITRUST Policx 130 (1959); Barnes, Competitive Mores and Legal Tests in Merger Cases: The du Pont-General Motors Decision, 46 GEo. L.J. 564, 589 (1958); Bok, Section 7 of the Clayton Act and the Merging of Law and Economics, 74 HARv. L. REv. 226, 272-74 (1960); Turner, Conglomerate Mergers and Section 7 of the Clayton Act, 78 HaRv. L. Rev. 1313, 1318-19 (1965). But see Bock, The Relativity of Economic Evidence in Merger Cases, 63 Mich. L. Rev. 1355, 1366 (1965); Dean \& Gustus, Vertical Integration and Section 7, 40 N.Y.U.L. REv. 672, 689-91 (1965).

39. Proctor \& Gamble Co., [1963-1965 Transfer Binder] TRADE REg. REP. II 16,673 at 21,574 (FTC 1963).

40. Id.

41. Union Carbide Corp., 59 F.T.C. 614,670 (1961).

42. Id. at 671 . Commissioner Kern's "market realities" would seem to be similar to the types of post-acquisition evidence Justice Stewart would find persuasive.

In Consolidated Foods, Justice Stewart relied heavily on post-acquisition evidence of alterations in the pattern of purchasing of the sunall food processors. His focus on the small processors reflected his pragmatic judgment that the alleged reciprocity power would function effectively only as to firms which have not established consumer ac- 


\section{District Court Decisions}

District courts have not adopted a uniform approach to post-acquisition evidence. Given the difficult job of predicting future effects, several district courts appear to have reached out for concrete evidence rather than rely upon arguments based solely on economic theory. ${ }^{48}$ The decisions invariably pay hip service to the predictive nature of section 7 proceedings, but in the final analysis, several have upheld mergers merely because trial took place several years after merger and the government failed to establish some actual anticompetitive effects. ${ }^{41}$ In

ceptance. Looking merely to the percentage potentially foreclosed disregards the substantial power major food processors have because of consumer acceptance. 380 U.S. at 607.

In Von's Grocery, Justice Stewart emphasized the large number of small competitors, the absence of significant barriers to entry, and frequent price wars in the four years after the merger. Whatever anticompetitive effects might be expected to result from the merger as a matter of theory, the continued functioning of competition in almost classic fashion provides the basis for assessing the merger's present effects on the market mechanism and there is nothing to indicate "that there is more than an ephemeral possibility that the effect of this merger may be substantially to lessen competition." 384 U.S. at 304 (dissenting opinion).

In Union Carbide Corp., 59 F.T.C. 614 (1961), Commissioner Kern pointed out that the competitors allegedly foreclosed from dealing with the acquired firm remained competitively strong, that those competitors testified that competition remained vigorous and dynamic, that the acquired firm's competitors have been expanding, that the product has been selling at a lower price, and that many new entrants have appeared.

43. United States v. National Steel Corp., 251 F. Supp. 693 (S.D. Tex. 1965); United States v. Von's Grocery Co., 233 F. Supp. 976 (S.D. Cal. 1964); United States v. Continental Can Co., 217 F. Supp. 761 (S.D.N.Y. 1963); United States v. Lever Bros. Co., 216 F. Supp. 887 (S.D.N.Y. 1963); United States v. Aluminum Co. of America, 214 F. Supp. 501 (N.D.N.Y. 1963).

Several courts seem to have relied exclusively on post-acquisition evidence.

The evidence respecting the economic conditions existing during the years $1961,1962,1963$, would appear to be far more reliable as a guide in determining the effect of the merger than the 'prognosis' mentioned in Brown Shoe.

United States v. Von's Grocery Co., 233 F. Supp. 976, 984 (S.D. Cal. 1964).

The above is proof of what has actually happened in the competitive market. It is a competitive reality much more convincing than arguments based on speculative future market conditions. When such facts are supported by the oral testimony of utility purchasing agents and non-integrated manufacturers to the effect that the acquisition has not adversely affected their businesses, a finding of a substantial lessening of competition is precluded.

United States v. Aluminum Co. of America, 214 F. Supp. 501, 517 (N.D.N.Y. 1963). 44. In rejecting the argument that Continental's acquisition of Hazel-Atlas had eliminated potential competition, the district court concluded:

The difficulty with this position [the Government's contention that Continental would restrict Hazel-Atlas' development of new glass containers] was that the evidence failed to show that, had the acquisition not taken place, there was any reasonable probability that Hazel-Atlas would become a significant competitive factor in the manufacture of beer bottles.

United States v. Continental Can Co., 217 F. Supp. 761, 796 (S.D.N.Y. 1963). The district court in Von's Grocery refused to ignore "facts which would, with a reasonable degree of certainty, establish whether or not there was reasonable probability 
all types of merger cases, whether horizontal, ${ }^{45}$ vertical ${ }^{46}$ or conglomerate, ${ }^{47}$ some district courts have placed great weight on the absence of industry witnesses confirming the government's prognosis of anticompetitive effects.

The district courts appear most impressed by post-acquisition decreases in the market shares of merging firms, particularly in horizontal merger cases. ${ }^{48}$ One court, for example, has found evidence that the structure of the market remained competitive sufficient to rebut the argument that a horizontal merger between the third and eighth largest competitors constituted a major step toward oligopoly..$^{49}$

In vertical merger cases, courts have relied heavily upon post-ac-

of the lessening of competition." United States v. Von's Grocery Co., 233 F. Supp. 976, 984 (S.D. Cal. 1964). 1964).

45. See United States v. Von's Grocery Co., 233 F. Supp. 976, 981 (S.D. Cal.

46. See United States v. Aluminum Co. of America, 214 F. Supp. 501, 519 (N.D.N.Y. 1963); United States v. National Steel Co., 251 F. Supp. 693 (S.D. Tex. 1965).

47. See United States v. Continental Can Co., 217 F. Supp. 761, 807 (S.D.N.Y. 1963). The district court treated the acquisition by Continental (a leading metal container manufacturer) of Hazel-Atlas (a leading glass container manufacturer) as conglomerate. In reversing, the Supreme Court treated the merger as horizontal because of the significant end-uses for which glass and metal containers were interchangeable. 378 U.S. at $452-55$.

48. In United States v. Von's Grocery Co., 233 F. Supp. 976 (S.D. Cal. 1964), the court was impressed by the percentage decrease in the share of the market accounted for by the defendant.

In United States v. Aluminum Co. of America, 214 F. Supp. 501 (N.D.N.Y. 1963), the Governnent contended that the vertical merger would provide the merging firms with competitive advantages over its nonintegrated competitors. The district court pointed out that in two years after the merger, nonintegrated firms increased their share of market sales fron 29.8 percent to 33.5 percent while the defendant's share decreased from 16.3 percent to 13 percent. Id. at 517.

In Consolidated Foods Corp. v. FTC, 329 F.2d 623 (7th Cir. 1964), the court of appeals was impressed by Gentry's loss of 12 percent in its garlic sales and only a 7 percent increase in its onion sales despite the alleged power to induce purchases through reciprocity resulting from the merger. The court reasoned that:

[H]ere ten years of post-acquisition experience-during which Consolidated attempted overt enforcement of reciprocal buying practice where it deemed it might be successful-serves to demonstrate that neither the acquisition of Gentry, in and of itself, nor the overt attempts to use buying power to influence sellers to Consolidated to purchase from Gentry resulted in substantial anticompetitive effects.

Id. at 626 .

The absence of a decisive increase in Gentry's sales, and indeed its decrease in sales of one product, undercut the Commission's finding, "and absent some factors which requires a different approach we are of the view that the experience reflected by this post-acquisition period must weigh heavily in appraising future probabilities." Id. at 626. The court continually spoke in terms of probable future effects, but it made its prediction by reference to concrete market facts.

49. Umited States v. Von's Grocery Co., 233 F. Supp. 976, 981, 985 (S.D. Cal. 1964). 
quisition evidence in rejecting arguments that particular vertical mergers may injure competition by foreclosing nonintegrated competitors froin substantial sources of supplies or sales or by "squeezing" nonintegrated coinpetitors' profit margins. ${ }^{50}$ The courts also have relied upon evidence that nonintegrated competitors have increased their shares of the market or that continued vigorous competition in the supply market will protect the nonintegrated manufacturer from being disadvantaged..$^{61}$

None of the approaches described above provides a satisfactory resolution to a rather straightforward problem. The Supreme Court has disposed of the question of the defensive use of post-acquisition evidence with little inore than a statement of the obvious-that section 7 may be violated without proof of actual restraints. Nor are the F.T.C. arguments particularly convincing. On the other hand, several district courts appear to have relied indiscriminately on post-acquisition evidence, upholding a inerger where no actual effects have become apparent in the years between the merger and the trial.

\section{II}

\section{A RECOMMENDED APPROACH AND ITS APPLICATION}

Post-acquisition evidence can provide a trial court with a concrete basis on which to make the difficult prediction required by section 7 . It constitutes some writing on "a blank slate," something concrete in place of "untested speculation." Concluding that post-acquisition evidence can be useful is not equivalent to concluding that a defendant should be permitted to drown the court in a deluge of irrelevancies.

50. For example, the district court in United States v. Aluminum Co. of America, 214 F. Supp. 501 (N.D.N.Y. 1963), concluded:

This contention ignores the competition between primary aluminum producers and seems to assume without evidence to support it that such producers will abondon by an unconscionable pricing arrangement the market for primary aluminum and be content to sell only the end product. This overlooks entirely the present competitive situation among primary aluminum producers, the government required allotment of primary aluminum, and the availability of Canadian and foreign intermediate aluminum products. Id. at 518.

In United States v. Standard Oil Co., 1964 Trade Cas. 79,841 (N.D. Cal. 1964), the district court pointed to the Government's failure to produce one industry witness, despite a canvas of nearly every domestic refiner, to testify to the existence of a squeeze on relatively nonintegrated refiners' profit margins after the merger, or at least to the apprehension of such a squeeze in the future. "Plaintiff's own economic witness conceded that he had no evidence of a 'squeeze' on refiner margins .... He relied upon the mere fact that an acquisition had occurred eschewing any analysis which might indicate that the acquisitions in fact had no anticompetitive effects." Id. at 79,843. To support the conclusion that the merger did not give the defendants any significant competitive advantage, the court relied on the increasing share of the domestic oil refining market obtained by less integrated refimers in recent years.

51. See notes 48,50 supra. 
Mergers are not unlawful per se, ${ }^{52}$ but neither is their validity to be determined by a broad rule of reason inquiry. ${ }^{53}$ Courts liave imposed and should continue to impose limits to keep section 7 litigation from bogging down in a quagmire of equivocal evidence. ${ }^{54}$

A merger's effects on competition are to be determined at the time of suit rather than at the time of merger. ${ }^{55}$ If actual anticompetitive effects become apparent between merger and suit, a Sherman Act case is likely to be easy to establisl ${ }^{56}$ and there would be little sense in bringing a section 7 action based on probable effects. If no such actual effects have evolved, it is obvious that the suit must be concerned with what probably will occur in the future. ${ }^{57}$

Once it is recognized that probable anticompetitive effects are measured at the time of suit, it is clear that a blanket exclusion of postacquisition evidence is inappropriate. There is no reason to distinguish per se between pre-acquisition evidence and post-acquisition evidence arising before suit. Any profferred evidence, whether pre- or post-acquisition, may be deemed madmissible.

52. C. Kaysen \& D. Turner, Antitrust Policy 128-29 (1959); Bowman, Contrasts in Antitrust Theory: II, 65 Colum. L. Rev. 417 (1965); Hall \& Phillips, Antimerger Criteria: Power, Concentration, Foreclosure and Size, 9 VILL. L. REv. 211, 214 (1964); von Kalinowski, Section 7 and Competitive Effects, 48 VA. L. REv. 827, 830 (1962); Whitney, Mergers, Conglomerates, and Oligopolies: A Widening of Antitrust Targets, 21 Rutgers L. REv. 187, 197 (1967).

53. Although many of the motives underlying modern acquisitions are not "pernicious," many of thein are not particularly beneficial. Heflebower, Corporate Mergers: Policy and Economic Analysis, 77 Q.J. Econ. 537, 557-58 (1963); McGuire, Chin \& Elbing, Executive Incomes, Sales and Profits, 52 AM. EcoN. REv. 753, 756-58 (1962). Indeed, one economist has constructed an economic model based, not on the traditional concept that businessmen are inotivated by the profit maximization principle, but on a growth maximization principle. Baunol, On the Theory of Expansion of the Firm, 52 AM. EcoN. REV. 1078 (1962). It has been argued that economies alleged to justify inergers may be illusive. Hearings before the Subcomm. on Antitrust and Monopoly of the Senate Comm. on the Judiciary, 89th Cong., 1st Sess., pt. 3, at 1555, 1562 (testimony of Dr. John Blair), pt. 1, 181-82, 185 (testimony of Dr. Irwin Stelzer) (1965) [hereinafter cited as Hearings]. And finally, even where real economies result, it has been argued, they should not be accepted as a defense to an otherwise unlawful merger. Brown Shoe Co. v. United States, 370 U.S. 294, 344 (1962); Bok, Section 7 of the Clayton Act and the Merging of Law and Economics, 74 Harv. L. Rev. 226, 237 (1960). See United States v. Philadelphia Nat'l Bank, 374 U.S. 321, 362 (1963).

54. The F.T.C. proceedings involving acquisitions by Pillsbury Mills are a prime example of the hazards of "thorough" economic investigation. 50 F.T.C. 555 (1953). (1957).

55. See United States v. E.I. du Pont de Nemours \& Co., 353 U.S. 586, 597

56. The Sherman Act is aimed at conduct which has resulted in restraint of trade or in monoply, not conduct likely to result in such restraint. United States v. United States Steel Corp., 251 U.S. 417, 444 (1920); United States v. Columbia Steel Corp., 334 U.S. 495, 524 (1948).

57. Decisions, as well as logic, support this proposition. See United States v. E.I. du Pont de Nemours \& Co., 353 U.S. 586, 597 (1957). 
Since section 7 is structurally oriented, behavioral evidence may have bittle probative value. For example, in cases where a merger is alleged to be unlawful because it gives the defendant a power to impair competition, whether by forcing reciprocal buying or foreclosing competitors from dealing with the acquired firm, the defendant should not be permitted to defend the merger by showing it has not exercised that power. ${ }^{58}$ Obviously, the mere failure to exercise the power does not mean that it may not be exercised in the future. The success and existence of competitors should not depend on the acquiring firm's benevolent restraint in refraining froin using its power to impair competition. ${ }^{59}$

On the other hand, some types of behavioral evidence, particularly conduct or absence of expected conduct by the merged firms' competitors, can be significant. Even were the merging firms to refrain froin exercising the power resulting from the merger, the mere existence of a power to injure coinpetitors may affect conduct of the inerged firms' actual and potential competitors. ${ }^{60} \mathrm{~A}$ conglomerate merger introducing a very large firm into a market of significantly smaller firms may be challenged on the ground that smaller competitors will be intimidated and refrain from competing vigorously because of the threat of predatory pricing. Evidence that the merged firms' competitors continued to compete vigorously over a substantial period of time after the merger is strong evidence that the inerger has not had the alleged effects. This behavioral evidence reflects the assessment of the merged firms' competitors of the likely long-range impact of the merger. The merged firms have no control over acts resulting froin competitors' assessinent of the threat posed by the inerger, and such behavioral evidence goes to the root of the theory on which illegality is predicated. ${ }^{61}$

58. In addition to the obvious proposition that a firm should not have to depend on a competitor's refraining from putting it out of business, or at least severely impairing its competitive ability, there are great difficulties inherent in such an inquiry, as exemplified by the various Supreme Court opinions in Consolidated Foods.

59. In Uinted States v. Columbia Steel Co., 334 U.S. 495 (1948), the Court evaluated the effect of a vertical merger, proceeding from the proposition that: "A subsidiary will in all probability deal ouly with its parent for goods the parent can furnish." Id. at 523. See also Turner, Conglomerate Mergers and Section 7 of the Clayton Act, 78 HARv. L. Rev. 1313, 1389 (1965).

60. See FTC v. Proctor \& Gamble Co., 386 U.S. 568, 578 (1967). Cf. Turner, supra note 59 , at $1389-90$.

61. In rejecting the need to analyze the actual effects of the merger, the Commission has noted:

As has been pointed out, the conditions which retard competition in an industry are to au important degree psychological. They stem from competitors' appraisal of each other's intentions, rather than from the intentions-or the actions taken upon them-themselves. The appropriate standpoint for appraising the impact of this merger is, then, that of Clorox's rivals and of the firms which might contemplate entering the liquid bleach industry. To such firms, it is probably a matter of relative indifference, in setting business policy, 
Commentators have advocated and courts have adopted rules of presumptive illegality, based on economic theory, to keep section 7 cases manageable. ${ }^{62}$ Where these rules have been supported by empirical investigation, post-acquisition evidence should be limited to the key factors on which the presumptive rules are based. Absent strong support from economic theory and empirical investigation, courts should permit post-acquisition evidence as to any factor which logically bears on the merger's probable long-range competitive effect.

Preliminarily, the court should require the defendant to establish that the post-acquisition evidence which it intends to introduce was not subject to its control. In addition, it should apply a stringent test of relevancy. The court should disallow, for example, the introduction of statistics showing only a decrease in the defendant's market share and should require the defendant to explain the decrease in terins of market structure or other competitive factors which tend to show that the weakening in the defendant's position is not a short-run phenomenon.

\section{A. Rules of Presumptive Illegality and Post-Acquisition Evidence}

Although section 7 applies the same basic test to all types of mergers-whether the merger tends to lessen competition substantially-the precise way in which a merger may affect competition adversely depends largely on the functional relationship of the merging firms. Similar factors may be considered in different types of mergers, but the basic theories are likely to be dissimilar. ${ }^{63}$ Consequently, the validity of the defensive use of post-acquisition evidence must be evaluated in the terms of each separate category of challenged merger.

how actively a Proctor-owned Clorox pursues its opportunities for aggressive, market-dominating conduct. The firm confined by the high costs of shipping liquid bleach, and the high costs of national or regional advertising, within a geographically small area, cannot ignore the ability of a firm of Proctor's size and experience to drive it out of business (not necessarily deliberately) by a sustained local campaign of advertising, sales promotions and other efforts.

Proctor \& Gamble Co., [1963-1965 Transfer Binder] TrADE Reg. ReP. I 16,673, at 21,579 (FTC 1963).

62. See note 38 supra. Assistant Attorney General Edwin M. Zimmerman described the development of presumptive rules, with the attendant reduction in the magnitude of the investigation, as "a substantial judicial achievement." Address to the Antitrust Section of the American Bar Association, April 14, 1967.

63. Occasionally, vertical mergers have been alleged to be unlawful under theories applied to conglomerate mergers. In Reynolds Metal Co. v. FTC, 309 F.2d 223 (D.C. Cir. 1962), the court of appeals declined to rest its decision holding a vertical merger unlawful on the basis of the share of the market foreclosed. Rather it held the merger unlawful on the "deep pocket" theory. The intrusion into a market of pigmies by a giant such as Reynolds through acquisition enabled the acquired firm to employ Reynolds' profits from operations in other markets in undercutting its competitors' price. Id. at 229-30. 
The Department of Justice merger guidelines ${ }^{64}$ set out rules of presumptive illegality the Department will apply in determining whether to challenge a particular merger. For several reasons, these guidelines provide a convenient framework within which to examine the role postacquisition evidence can play in section 7 litigation. In part the guidelines summarize the rules already developed by the Supreme Court. ${ }^{\text {ob }}$ Furthermore, they may well point the way toward future development of rules by the Court. ${ }^{66}$ Finally, an inquiry into the value of defensive post-acquisition evidence will be meaningful only when keyed into the types of mergers which are likely to be challenged.

\section{B. Horizontal Mergers}

\section{Rule of Presumptive Illegality}

A merger of firms producing competitive products obviously reduces the number of competitors and increases market concentration. The elimination of a competitor, however, cannot per se be equated with a substantial lessening of competition. ${ }^{67}$ Despite notable aberrations, ${ }^{68}$ the antitrust laws generally have been enforced to protect the competitive process rather than individual competitors.

The guidelines establish two major tests to be apphed to horizontal

64. Department of Justice Enforcement Policy Merger Guidelines, 1 TRADE REO. REP. If 4430 (1968) [hereinafter cited as Merger Guidelines].

65. In United States v. Philadelphia Nat'l Bank, 374 U.S. 321 (1963), the Court mandated a rule of presumptive illegahty in horizontal merger cases based on market concentration:

Specifically, we think that a merger which produces a firm controlling an undue percentage share of the relevant inarket, and results in a significant increase in the concentration of firms in that market, is so inherently likely to lessen competition substantially that it must be enjoined in the absence of evidence clearly showing that the merger is not likely to have such anticompetitive effects.

Id. at 363.

In Consolidated Foods, the Court concluded that a violation could be predicated on the percentage of the inarket subject to reciprocity pressure:

[W] here, as here, the acquisition is of a company that commands a substantial share of a market, a finding of probability of reciprocal buying by the Cominission, whose expertise the Congress trusts, should be honored, if there is substantial evidence to support it.

380 U.S. at 600.

66. Then Assistant Attorney General Turner under whose direction the Merger Guidelines, supra note 64, were drawn has been a favorite source of supporting citations for Supreme Court section 7 decisions. The majority opinion in Proctor \& Gamble relied heavily on the theories Turner articulated in his article on conglomerate mergers. See Turner, Conglomerate Mergers and Section 7 of the Clayton Act, 78 HARV. L. REv. 1313 (1965).

67. Brown Shoe Co. v. United States, 370 U.S. 294, 344 (1962); Bork \& Bowman, The Crisis in Antitrust, 65 Colum. L. Rev. 363, 370 (1965).

68. Cases under the Robinson-Patman Act tend to provide greater opportunity for aberration since its basic theory is to ameliorate certain kinds of competition. See, e.g., Utah Pie Co. v. Contmental Baking Co., 386 U.S. 685, 702-03 (1967). 
mergers: one based on the degree of market concentration and the market share controlled by the merging firms, and the second based on the existence of a marked trend toward concentration. The tests are intended to prevent a merger if it would eliminate a substantial competitive influence, if it is likely to foster the development of dominance by one or a group of firms, if it would result in a significant increase in concentration, or if it would interfere with potential deconcentration. ${ }^{69}$

This enforcement policy is based on oligopoly theory which suggests that where each of the few leading sellers in a concentrated market accounts for a significant share of the market's sales, one firm can increase its share only at the expense of an identifiable competitor. ${ }^{\mathbf{7 0}}$ Thus a price cut by one seller is likely to be met by comparable cuts by the others, and as a result the firms will retain roughly the same share of the market but receive a lower gross revenue because of the lower price per unit. ${ }^{71}$

By recognizing their mutual best interests, the firms jointly may exercise market power without any overt agreement. ${ }^{72}$ Indeed, the inability to deal with consciously parallel, oligopoly pricing has proven to be a grave weakness in antitrust enforcement. ${ }^{73}$ One solution is to prevent the evolution of oligopolistic markets by preventing horizontal mergers which threaten to create them.

There has been vociferous dissent, at times approaching brobdignagian proportions, from too heavy reliance on oligopoly theory and concentration and market share statisties. ${ }^{74}$ Nevertheless, the critics

69. Merger Guidelines, supra note 64, at II 6683 .

70. The Court has indicated that section 7 , like the other antitrust laws, embodies social and political as well as economic policies. See Brown Shoe Co. v. United States, 370 U.S. 294, 344 (1962). Although the Court has not appeared to rely on the social and political considerations in reaching any of its anti-merger decisions, those considerations often are cited as supporting the Court's rulings. Blake \& Jones, Toward a Three-Dimensional Antitrust Policy, 65 Colum. I. REv. 422, 431 (1965). See also M. Massel, Comperrmon \& MoNopoly 19-21, 42 (1964); Bok, Section 7 of the Clayton Act, and the Merging of Law and Economics, 74 HaRv. L. REv. 226, 236 (1960).

71. The degree of vigor of price competition in an oligopoly generally depends on a blend of two opposite tendencies. The first is the recognition that each seller can maximize his profit by maximizing industry profit. The second is the natural antagonism between competitors which prevents any seller from relying completely on his competitors. J. BAIN, PrICE THEORY 278 (1963 ed.).

72. Turner, The Definition of Agreement Under the Sherman Act: Conscious Parallelism and Refusals to Deal, 75 HARv. L. REv. 655, 666 (1962).

73. C. KAYSEN \& D. TURNER, ANTIIRUST POLICY 110 (1959).

74. United States v. Von's Grocery Co., 384 U.S. 270, 282-83, 297 (1966) (Stewart, J., dissenting); Adler, Merger Rules and Supreme Court Economics, 36 ANTITRUST L.J. 4, 6-9 (1967); Carlston \& Treece, Antitrust and the Consumer Interest, 64 MiCH. L. REv. 777, 797-99 (1966).

"If recent Supreme Court pronouncements provide a guide, the trend in enforcement of competition is toward mcreasing reliance upon a pluralistic inodel of a com- 
generally have failed to offer a feasible alternative to focusing on a few key factors, short of a full-blown rule of reason inquiry which Congress wished to avoid and which would effectively destroy the prophylactic effect of section $7 .{ }^{75}$ In addition, there has been sufficient, albeit not overwhelming, einpirical support for rehance on oligopoly theory. ${ }^{\mathbf{7 0}}$

\section{Horizontal Mergers and the Recommended Approach}

The percentage of the market controlled by the merging firms, the degree of concentration, the trend toward or away froin concentration, the condition of entry, and the vigor of competition are minimal factors on which courts should permit defendants to build a defense based on post-acquisition evidence. Each may be proven by objective evidence, uncontrollable by defendants. The first three relate fundamentally to market structure. The fourth relates to actual performance which, when placed in a particular market structure, might provide the best basis for predicting future competitive effects. In a sense the fourpart division is artificial. The three structural factors are obviously related, as is the fourth insofar as a firm's decisions must be made with a view to the market structure $\mathrm{m}$ which the firm is operating.

The following discussion will focus on decreases in the defendant's market share and the condition of entry into the market. Both are discussed in terms of concentrated markets and those which, although not yet concentrated, are undergoing a discernible trend toward concentration.

\section{a. Decreasing Market Shares}

The Court and the Justice Department have focused priniarily on the defendant's share of the market and the degree of market concentration as the prime indicators of a horizontal merger's likely effect on coinpetition. ${ }^{77}$ In view of this market share approach to horizontal

petitive market-one with many sellers, preferably independent and locally ownedagamst which to measure challenged marketing arrangements." Id. at 784. "To attempt to establish the model of highly pluralistic competition as the ideal model for the purposes of public policy and decisionmaking is to substitute a crude symbolic representation for a complex reality." Id. at 799 . "[R]ecent antitrust decisions, at least in the merger field, have tended increasingly and in substantial ways to rest on considerations unsupported, and sometimes in conflict with, the economic logic of competition. Markham, Current Decisions in Antitrust, 12 ANTITRUst Bull. 851, 853 (1967).

75. See, e.g., Whitney, supra note 56, at 234.

76. Stigler, Industrial Organization and Economic Progress, in H. LEviN, BusINess Organization and Public Policy 131-33; Speech by Assistant Attorney General Donald F. Turner, Institute of Advanced Legal Studies, June 5, 1967.

77. Brown Shoe Co. v. United States, 370 U.S. 294, 343 (1962); United States v. Pliiladelphia Nat'1 Bank, 374 U.S. 321, 364-66 (1963); United States v. Von's Grocery Co., 384 U.S. 270, 272-74 (1966).

There has been dissent from undue reliance on inarket shares. See, e.g. Adler, 
mergers, defendants frequently have pointed to a decline in their aggregate market share after the merger as tending to prove that the inerger is not likely to lessen competition in the future. ${ }^{78}$ Since market shares are the primary indicia of market power, defendants argue, where merging firms have suffered a significant post-acquisition decline in their market share, the merger has not had any anticompetitive effects. The failure of anticoinpetitive effects to evolve in the post-acquisition period estabhishes that they are not likely to result froin the merger some time in the future.

Both the Supreme Court and the F.T.C. have rejected this argument on the ground that such a decrease is equivocal. Absent the merger, either or both of the merging firms might have suffered greater declines. While such a "but for" test is conceptually justified, strict adherence to such a test would preclude consideration of a post-acquisition decrease unless the defendant could discharge the insurmountable burden of establishing that its share would not have decreased further without the merger. Of course, the inore nearly the market involved approximates the competitive ideal, the less compelling is the need to adhere strictly to the "but for" test.

Defendants should not be permitted to establish a defense inerely by showing a post-acquisition decrease in their market share. A decrease of a particular magnitude may be significant evidence of likely future effects if it is combined with other factors which place the decrease in the context of the particular market. Such factors may include the degree of market concentration, the inovement of the industry toward increased concentration or deconcentration, the expansion or contraction of deinand, the inerging firms' pre-acquisition positions in the market, and the post-acquisition position of the market's smaller firms.

For example, concentration normally decreases where demand increases and increases where demand decreases. Therefore, a decrease in the defendant's market share in the face of decreasimg demand in the market as a whole, that is, in a market becoming more concentrated, would appear to indicate that the defendant's position in the market is relatively weak. Such a decrease is most persuasive in favor of a merger's validity where smaller firms in the market have strengthened their position at the defendant's expense.

Merger Rules and Supreme Court Economics, 36 ANTITRUST L.J. 4 (1967); Whitney, supra note 52, at 226-67. See also Dean \& Gustus, Vertical Integration and Section 7, 40 N.Y.U.L. REv. 672, 689-91 (1965); von Kalinowski, Section 7 and Competitive Effects, 48 VA. L. Rev. 827, 852 (1962).

78. United States v. Von's Grocery Co., 384 U.S. 270, 290-92 (1966) (Stewart, J., dissenting); United States v. National Steel Corp., 251 F. Supp. 693, 699 (S.D. Tex. 1965); Fruehauf Trailer Co., [1963-1965 Transfer Binder] Trade REg. ReP. II 16,714 (FTC 1964); Kaiser Indus., [1963-1965 Transfer Binder] TRADE REg. ReP. II 16,529 (FTC 1963). 
It is impossible to set out precise percentages which should weigh heavily in favor of a inerger's validity; the selection of any percentage is somewhat arbitrary. Certainly in a relatively fragmented market a decrease in the defendant's market share equivalent to the share of one of the merging firms at the time of merger is entitled to great weight. In the absence of a trend toward concentration in the post-acquisition period any significant decrease should be persuasive.

In an oligopolistic market, a decrease equal to the share controlled by one of the merging firms at the time of merger should weigh heavily in favor of a merger's validity, even when tested in terms of the four basic policies underlying the guidelines. First, such a decrease eliminates the increased concentration resulting from the merger. Second, with the reduced concentration the likelihood that the acquiring firm, or a small group of firms including the acquiring firm, will obtain, or entrench itself in, a dominant position is significantly reduced. Third, the decrease in the share possessed by the merging firms would indicate that significant possibilities for deconcentration may remain, particularly where the loss is to the market's smaller firms.

As to the remaining policy, preventing ehmination of an independent competitor likely to have been "a substantial competitive influence," a post-acquisition decrease is irrelevant. If the Government can establish that the acquired firm was a substantial competitive influence and the market was oligopohistic, the defendant should be required to show not only that it sustained a significant decrease in its market share but also that one or more efficiently sized firms entered the market and that the share of the market controlled by the four to eight largest firms has not increased. Such a showing supports the inference that whatever influence the acquired firm had as an independent competitor is being provided by the new entrants. If the leading firms in the industry have failed to enhance their positions, the market has not been injured by the merger.

A post-acquisition decrease should be most persuasive where the defendant can attribute the decrease to a fundamental alteration in the market. For exainple, the development of new end uses for a particular product may result in an increase in demand sufficient to induce new entry or expansion by smaller firms operatimg below the optimum efficiency level. Or a sigmificant change in technology may reduce the minimum level at which maximum efficiency may be obtained. Smaller firms will be better able to coinplete with market leaders.

A decrease in the defendant's market share in an olgopoly market should be most persuasive where the market is undergoing a discernible trend toward deconcentration. The existence of such a trend is strong evidence that objective market factors will ensure that the market 
reaches the competitive level which its structure dictates. Under these conditions the eroding position of the leading firms has obviously not been stemmed by the merger. In addition, the decrease in its share of the market inakes it highly unlikely that the particular defendant was able to preserve, much less enhance, its dominant position through the merger. Balancing the minimal constructive advantage to be gained from overturning the merger against the risk of economic dislocation frequently accompanying divestiture, the scale seems to tip in favor of permitting the merger to stand.

\section{b. Condition of Entry and New Entrants}

Defendants might point to the fact that there were no significant barriers hindering entry by new firms after the merger or that new firms have entered the market as proving that the merger is not likely to imjure competition. ${ }^{70}$ The Supreme Court seems to have rejected the absence of significant barriers to entry as a defense on the ground that the existence of potential competition cannot compensate for the loss of actual competition. ${ }^{80}$ It has reasoned that the mere fact the market may be conducive to new entrants over a period of time does not alleviate the adverse impact resulting from the elimination of a competitor, particularly in an already oligopolistic market. ${ }^{81}$

The condition of entry imto a market is a "potentially strategic dimension of market structure" which must be considered in predicting a merger's long range impact. ${ }^{82}$ The condition may range from easy entry, where established firms have no significant advantages over potential entrants and are unable to raise their prices above the

79. The district court in United States v. Continental Can Co., 217 F. Supp. 761 (S.D.N.Y. 1963), relied on the ease of entry into the various lines of commerce suggested by the Government only to have the Supreme Court reverse without referring to ease of entry. United States v. Continental Can Co., 378 U.S. 441 (1964). See also, EKCO Prods. Co., [1963-1965 Transfer Binder] REg. REP. If 16,879 (FTC 1964), aff'd, EKCO Prods. Co. v. FTC, 347 F.2d 745 (7th Cir. 1965).

80. See United States v. Von's Grocery Co., 384 U.S. 270 (1966).

81. Emphasis on short-run effects seeins questionable. Section 7 is supposedly concerned with structural changes which have a long-range anticompetitive impact. FTC v. Proctor \& Gamble Co., 386 U.S. 568, 577 (1967); United States v. Von's Grocery, 384 U.S. 270, 275 (1966); Barnes, Competitive Mores and Legal Tests in Merger Cases: The du Pont-General Motors Decision, 46 Geo. L.J. 564, 621 (1958). Indeed, the Court has been criticized in other cases for over-emphasizing market structure. Blackford, Vertical Acquisition and Section 7 of the Clayton Act, 17 W. Res. L. Rev. 102, 128 (1965). See also Carlston \& Treece, Antitrust and the Consumer Interest, 64 Mich. L. Rev. 777, 781 (1966).

82. J. Bain, Barriers to New Competition (1956). The condition of entry into a market may be viewed as "the advantages of established sellers in an industry over potential entrant sellers, these advantages being reflected in the extent to which established sellers can persistently raise their prices above a competitive level without attracting new firms into the industry." Id. at 3 (emphasis original). 
competitive level without attracting entry, to blockaded entry, where established firms have so great an advantage over potential sellers that the most favored established firms can charge a price which maximizes their profits without attracting entry. Factors such as the capital investment required to enter the market at an efficient level, the degree of control of production techniques through patents or the like, the availability of factors of production, the degree of product differentiation and the existence of significant economies of scale determine the condition of entry. It is not equivalent to or necessarily evidenced by the actual pattern of entry. The absence of new entry does not establish that entry barriers are high. Successful entry at an efficient size does, however, make it unlikely that there are significant barriers to entry. Successful new entrants into a concentrated market may mitigate or even coinpletely eliminate both the increased concentration and the tendency toward increased parallel pricing which may accompany a horizontal merger. ${ }^{83}$

(i). Concentrated market.-The absence of significant barriers to entry in a concentrated market should not be considered persuasive. First, the fact that a-market is concentrated generally indicates there is some barrier to entry. Second, at best the absence of significant entry barriers will satisfy only two of the four policies underlying the merger guidelines; it may prevent the evolution of dominance by a small group of firms, and may prove that opportunities for deconcentration exist. The absence of entry barriers cannot, however, compensate for the loss of the acquired firm if it was a significant competitive factor. Potential competition can rarely, in fact, substitute for actual competition. ${ }^{84}$ Nor does the mere amenability to entry amehorate the increased concentration resulting from the merger.

Courts should, however, permit a defendant to establish that there has been significant post-acquisition entry. What entry is "significant" should be determined by reference to the four pohcies underlying the merger guidelines. The post-acquisition entrants must mitigate any increase in concentration resulting from the merger. They must at least replace the acquired firm as a competitive factor in the market. They must eliminate whatever increased likelihood of dominance resulted from the merger. The new entrants must be efficiently sized. Entry by firms unable to operate at an efficient scale is unlikely to be competitively significant.

83. A key factor in the significance of the impact of potential competition is the time gap between the decision to enter and the time when actual operations can be commenced. Id. at 11 .

84. The time gap between the origin of the factors motivating the decision to enter and the commencement of operations by the new entrant is one reason for the less significant impact of potential competition. $I d$. at 18 . 
Evidence of post-acquisition entry should be particularly persuasive where the optimum efficiency level is relatively high and requires output constituting a high percentage of the total demand. In this situation, the market is likely to end up with the same number of effective competitors in the long run regardless of the merger. A prediction of probable competitive impact should be based largely, if not exclusively, on the structure of the market. A market is not likely to be less coinpetitive where it can only support, for example, ten efficiently-sized firms, one of which is lost by merger but subsequently is replaced by a new entrant.

(ii). Fragmented market.-The fragmented market is close to the ideal competitive model, of which the absence of significant entry barriers is a major characteristic. As long as there are no significant barriers to entry, the fragmented market is likely to remain competitive. ${ }^{85}$ Unless there is a substantial post-acquisition trend toward concentration, courts should accord considerable weight in favor of a merger's validity to the absence of significant entry barriers. The weight given such evidence should increase as the share of the market controlled by the merged firms decreases.

Most often, a merger in a fragmented market will be challenged only where there is a discernible trend toward concentration. Such a trend often reflects some structural change in the market which raises barriers to entry. In other markets, where the trend results from mergers, the absence of significant entry barriers after the merger which is challenged will reverse the increase in concentration. Such a reversal may, however, take a considerable period of time. Therefore, unless one's concern is solely with the long range impact of a merger, it would not be difficult to reject the absence of significant entry barriers as a defense in a market characterized by a trend toward concentration, regardless of the cause of the trend.

Even in fragmented markets which are undergoing a period of increasing concentration, post-acquisition entry by efficiently sized firms may be sufficient to exonerate a merger. As long as the market contains the maximum number of efficiently sized firms, it cannot be said that the merger has probable anticompetitive effects. Therefore, post-acquisition entry of efficiently sized firms will ensure that market concentration will be no greater than that dictated by market structure. Only where the acquired firm was a unique competitive factor may subsequent entry fail to compensate for the loss of the acquired firm. Where, for exainple, the acquired firm was a particularly effective in-

85. When entry into a market is uninhibited, by definition any attempt by established sellers to raise their price above the competitive level will attract new entry which will drive down the price. Id. at 21 . 
novator, entry even by efficiently sized firms may not compensate for the loss of the acquired firm.

Unless the acquired firm was a unique competitive factor, postacquisition entry by efficiently sized firms will satisfy the four policies underlying the merger guidelines. The competitive influence of the acquired firm, simce it was not based on unique factors, is likely to be replaced by the new entrants. Indeed, post-acquisition evidence can establish whether the new entrant or entrants were able to compete effectively. Successful competition by new entrants will as effectively prevent one or a few firms from becoming dominant as competition by the acquired firm would liave done. Whether the new entrants have eliminated the imcreased concentration resulting from the merger will, of course, depend on the source of their success, which again can be established by market experience. ${ }^{86}$ Post-acquisition success by new entrantrants will provide the opportunity for deconcentration by encouraging either additional new entry or expansion by the new entrants.

\section{c. Vertical Mergers}

\section{Rules of Presumptive Illegality}

According to the merger guidelines, a vertical merger between firms im a buyer-seller relationship may substantially lessen competition by raismg entry barriers or by giving the merging firms competitive advantages over nonintegrated competitors. ${ }^{87}$ Foreclosing competitors from purchasing supplies from, or making sales to, the merging firms may niake new entry at an efficient production level difficult or even require entry on an integrated basis. Indeed, the mere tlireat of foreclosure (or a supply or price squeeze), unaccompanied by actual con-

86. Conceivably, the new entrants may obtain sales at the expense of the smaller firms in the market and thereby increase concentration.

87. The Court's decision in Brown Shoe Co. v. United States, 370 U.S. 294 (1962) (foreclosing competitors from a significant share of a market-tendency to elininate opportunities for sinall, single-line firms), would appear to have recognized the less direct competitive threat in establishing a modified rule of reason as to vertical mergers along the lines of Tampa Electric Co. v. Nashville Coal Co., 365 U.S. 320 (1961). Blackford, Vertical Acquisition and Section 7 of the Clayton Act, 17 W. REs. L. REv. 102, 118 (1965); Bock, The Relativity of Economic Evidence in Merger Cases, 63 Mrch. L. Rev. 1355, 1357 (1965); Bodner, Vertical Mergers Under Section Seven, 22 ABA ANTITRUST SECTION 106, 116 (1963). But as several commentators have recognized, subsequent decisions have moved toward more stringent tests of illegality. Blackford, supra, Bock, supra, at 1361-62. See Reynolds Metals Co. v. FTC, 309 F.2d 223 (D.C. Cir. 1962) (competitive advantages in the form of price subsidy); United States v. Kennecott Copper Corp., 231 F. Supp. 95 (S.D.N.Y. 1964) (trigger further mergers which will eliminate opportunities for small independent firms). See generally Barnes, Competitive Mores and Legal Tests in Merger Cases: The du PontGeneral Motors Decision, 46 GEo. L.J. 564, 584 (1958); Bodner, supra, at 116; Dean \& Gustus, Vertical Integration and Section 7, 40 N.Y.U.L. REv. 672, $689-91$ (1965) (price squeeze). 
duct may deter entry. The same factors likely to deter new entry are also likely to inhibit those in the market from competing too vigorously or expanding. ${ }^{88}$

The guidelines convert this theoretical analysis into rules by reference to the market shares controlled by the merging firms in their respective markets. Referring to the competitive impact in the supply market, a merger between a supplier with ten percent of the sales in the supply market and a purchaser with six percent of the purchases by its market is presumptively unlawful unless there are no significant entry barriers to the purchasing market. Referring to the competitive impact in the purchase market, a merger between a supplier with 20 percent of its market's sales and a purchaser with ten percent of the sales in its market is unlawful if the supply product is a complex one in which innovation has been taking place or is a scarce product whose supply cannot readily expand to meet increased demand..$^{89}$

\section{Vertical Mergers and the Recommended Approach}

Defendants should be permitted to introduce evidence slowing that the share of the market potentially foreclosed by the merger has decreased below the level set forth in the guidelines or that entry by nonintegrated firms has not been affected. Except in the rarest of cases, evidence that the defendant did not actually foreclose its competitors from dealing with the acquired firm should not be accorded significant weight.

\section{a. Insubstantiality of Potential Foreclosure}

Assuming that the merger is alleged to be unlawful because of the percentage of the market potentially foreclosed, the court should at least permit the defendant to establish that the relevant percentages decreased in the post-acquisition period below the levels set out as estabhishing a prima facie case in the merger guidelines. The defendant would not be using the decrease to prove directly that competition remained vigorous, but rather to prove that the basis on which the merger is presumed to be unlawful no longer exists. Where the share of the market potentially foreclosed is not substantial, the anticompetitive effect is not likely to be substantial.

Expansion by existing competitors or new entrants may cause the decrease. In either event, a significant post-acquisition increase in alternate sources of supply or sales outlets will negate the conclusion that the merger is likely to have a substantial anticompetitive impact. Un-

88. Merger Guidelines, supra note 64 , at $6685-87$; cf. C. KAYSEN \& D. TURNER, supra note 52, at 120, 122, 125.

89. Merger Guidelines, supra note 64 , at 6685-86. 
less independent competitors, actual or potential, are likely to be disadvantaged by a restricted supply or sale market, the merger neither raises entry barriers nor creates significant competitive, or anticompetitive, advantages. In effect, there will be sufficient alternatives to permit vigorous competition by unintegrated competitors, and any anticompetitive effects will be insubstantial.

Of course, where integration was high before the merger, additional sources of supply may do no more than partially mitigate the anticompetitive effects of the merger. In the absence of the merger, expansion comparable to that occurring in the post-acquisition period would have provided additional opportunities for nonintegrated competitors. Consequently, unless the defendant can establish that the sources of supply evolving in the post-acquisition period would not liave developed in the absence of the merger, the development of additional supplies should constitute a defense only if the percentage of the market potentially foreclosed becomes insignificant.

\section{b. Lack of Actual Foreclosure}

In answer to the argnment that a merger gave the merging firms the power to foreclose competitors from a substantial sliare of the market, a defendant might offer evidence tending to show that the acquired supplier continued to deal with the acquiring firm's competitors, or vice versa. Only im rare cases, where there are powerful economic reasons compelling the merging firms to continue dealing equally with all suppliers and purchasers, should the court consider post-acquisition evidence of lack of foreclosure. ${ }^{90}$ The mere existence of the power, even where unexercised, may be sufficient to discourage new entry or to deter present coinpetitors from competing vigorously.

The defendant's failure to exercise its power over nonintegrated competitors may result from any of a number of factors, none of which provide any assurance that the power will not be exercised at some time in the future. First, the threat of a section 7 action may provide a powerful impetus to refrain from cutting off nonintegrated competitors or squeezing their cost-profit margin. Second, one of the merging firms may be unable to supply (or purchase) the full requirements of

90. In United States v. Kennecott Copper Co., 231 F. Supp. 95 (S.D.N.Y. 1964), the trial court found that Kennecott did not favor its acquired fabricator in periods of shortage, but rather it dealt with all fabricators on an allocation system based on past purchases. Kennecott's failure to favor its acquired subsidiary was attributable to sound busimess judgmeut. In the long ruu, it would have damaged its business by favoring its acquired subsidiary at the expense of larger purchases. Id. at 105. Nevertheless, the mere existence of power to injure competition may injure coinpetition without overt exercise. Id. Cf. Reynolds Metal Co. v. FTC, 302 F.2d 223 (D.C. Cir. 1962); United States v. Ingersoll-Rand Co., 218 F. Supp. 530-52 (W.D. Pa. 1963). 
the other for a substantial period of time until it expands its operations. Third, one or both of the merging firms may have a policy which favors operating the two as independent firms. ${ }^{91}$

\section{c. Patterns of Entry and Trend Toward Integration}

Whether the merger is alleged either to raise entry barriers or to give the merging firms a competitive advantage, discouraging actual or potential competition, courts should permit defendants to prove that nonintegrated firms entered the market after the merger or that firms in the market have not been motivated to integrate as a defensive measure.

Courts should allow a defendant to slow that efficiently sized nonintegrated firms entered after the merger. Many subtle factors come into play in determining whether to enter a new market, not the least of whicli are the nature of the market (concentrated, integrated, etc.) and the ability of the new entrant to operate successfully in it. ${ }^{92}$ Sucli entry constitutes a pragmatic judgment, buttressed by an investment of substantial resources, by nonintegrated firms that whatever competitive advantages may have resulted from the merger are not likely to have a significant anticompetitive effect. To ignore such evidence is to elevate economic theory beyond Olympian heights, to rely on logical constructs in the place of judgments by those who are intimately familiar with the market and who are placing their reputations and financial fortunes on the line. The same analysis applies whether there are new entrants or whether there is expansion by a nonintegrated competitor already in the inarket. The latter may, however, be entitled to somewhat less weight since the cost of expansion generally is less than the cost of entry.

A comparison of patterns of action by nonintegrated firms before and after the inerger would also be instructive. Vigorous and successful competition by nonintegrated firms in the post-acquisition period is a significant indication that whatever advantages resulted from the inerger have not intimidated nonintegrated firms. ${ }^{93}$ An absence of significant attempts by nonintegrated firms to compensate for the alleged coinpetitive advantages, whether by merger or long-term requirements contracts, is a further indication of the assessment by those in the market as to the likely effects of the merger. If the merger re-

91. See United States v. Penick \& Ford Ltd., 242 F. Supp. 518 (D.N.J. 1965); United States v. Continental Can Co., 143 F. Supp. 787 (N.D. Cal. 1956).

92. See Pitofsky, Joint Ventures under the Antitrust Laws: Some Reflections on the Significance of Penn-Olin, 82 HARv. L. REv. 1007 (1969).

93. In United States v. Standard Oil Co. of Indiana, 1964 Trade Cas. II 71,215 (N.D. Cal. 1964), the district court upheld integrated oil producers' purchases of Honolulu Oil Corporation's oil-producing properties. The court rehed in part on continued vigorous coinpetition by relatively unintegrated oil refiners. $I d$. at 79,844. 
sulted in significant competitive advantages or threatened to foreclose nonintegrated competitors from a substantial share of the market, the nonintegrated firms logically would attempt to integrate. ${ }^{04}$ Evidence of the competitive efforts and successes of nonintegrated firms, whether new entrants or already in the market, is not subject to control by the defendant and reflects the assessinent of those purportedly threatened by the merger. The greater the time between the inerger and the suit, the more significant is the absence of a discernible movement by unintegrated firms to integrate.

\section{Conglomerate Mergers}

The term "congloinerate inergers" is used generally to denote all mergers which are neither horizontal nor vertical-where the merging firms are neither coinpetitors nor stand in a buyer-seller relationship. Because of the absence of some such direct relationship, the potential anticoinpetitive effects of conglomerate mergers are not as obvious as in horizontal or vertical merger cases. On the other hand, the same lack of a direct relationship makes it less likely that beneficial economies will be lost in the event the inerger is overturned..$^{05}$

Despite soine question as to the practicability of applying Section 7 to conglomerate mergers, the merger guidelines suggest three theories under which the Department will challenge such mergers: ${ }^{20}$ (1) Con-

94. Indeed, it is precisely this "triggering" effect which has been asserted as a basis for holding vertical mergers unlawful. United States v. Kimberly-Clark Corp., 264 F. Supp. 439, $446-47$ (N.D. Cal. 1967); United States v. Ingersoll-Rand Co., 218 F. Supp. 530 (W.D. Pa. 1963), aff'd, 320 F.2d 509 (3d Cir. 1963); Union Carbide Corp., 59 F.T.C. 614,652 (1961).

95. Blair, The Conglomerate Merger in Econimics and Law, 46 Geo. L.J. 672, 679-80 (1958).

96. Neither of the opinions the Court has written in the two conglomerate merger cases is particularly useful in determining what facts will support the various theories under which a conglomerate nierger nuay lessen competition. See FTC v. Proctor \& Gamble Co., 386 U.S. 568 (1967); FTC v. Consolidated Foods Corp., 380 U.S. 592 (1965).

The anticompetitive threat from a conglomerate merger is less obvious than from a horizontal or vertical merger because of the absence of a competitive or buycr-seller relationship, and therefore a less stringent rule of presumptive illegality would appear justified. Turner, supra note 38, at 1321 . On the other hand, the lack of some direet relationship makes less likely the existence of economies as a result of the merger. Id. at 1320 .

The FTC's opinion in Proctor \& Gamble, even more than the Supreme Court opinion, clearly articulated the more prominent theories likely to be used in section 7 actions against conglomerate mergers. 63 F.T.C. 1465 (1963). Reciprocity has been used in Consolidated Foods, and United States v. General Dynanics Corp., 258 F. Supp. 36 (S.D.N.Y. 1966). See also United States v. Koppers Co., 202 F. Supp. 437 (W.D. Pa. 1962). Several economists have indicated that cconomic theory has not developed sufficient evidence to make a sound judgment on conglomerate mergers. Hearings, supra note 53, at 36, 55 (testimony of Dr. Corwin Edwards), 248 (testimony of Dr. Walter Adams). It seems likely that the legal status of conglomerate nuergers will be established before a thorough economic understanding of such mergers is 
glomerate mergers may create substantial opportunities for reciprocal buying, ${ }^{97}$ (2) conglomerate mergers may eliminate potential competition, ${ }^{88}$ and (3) conglomerate mergers may tend to entrench existing market power. ${ }^{99}$

\section{Reciprocity}

The most popular theory thus far employed by the enforcement agencies in challenging conglomerate mergers is that they create an opportunity for reciprocal buying. Reciprocity is the business practice whereby a firm with purchasmg power induces those firms from whom it buys to purchase from it or its subsidiary. ${ }^{100}$ The practice is economically significant when a firm makes sales it would not have made otherwise. $^{101}$ It is objectionable because it permits a firm to make sales based on its purchasing power rather than on the merits of its products.

Reciprocity may appear in the form of overt exercise of buying power by threatening withdrawal of purchases; ${ }^{102}$ a voluntary agreement based on mutual benefit; ${ }^{103}$ a mere selling point; ${ }^{104}$ or an inde-

achieved. Whitney, supra note 52 , at 187 .

The controversy as to the relative efficiency of small, large, and larger firms continues to rage in terms of the benefits or lack of them accruing from conglomerate mergers. Compare Blair, The Conglomerate Merger in Law and Economics, 46 GEO. L.J. 672, 679-81 (1958); Hearings, supra note 53, at 185 (testimony of Dr. Irwin Stelzer); Rostow, The New Sherman Act: A Positive Instrument of Progress, 14 U. CHI. L. REv. 567, 568 (1947), with Adelman, Effective Competition and the Antitrust Laws, 61 HARv. L. Rev. 1289, 1291-92 (1948) and Whitney, supra note 52, at 198 .

97. FTC v. Consolidated Foods Corp., 380 U.S. 592 (1965); Umited States v. General Dynamics Corp., 258 F. Supp. 36 (S.D.N.Y. 1966).

98. See FTC v. Proctor \& Gamble Co., 386 U.S. 568 (1967); United States v. Penn-Olin Chem. Co., 378 U.S. 158 (1964).

99. It may do so either by permitting the acquired firm to rely on the conglomerate's "deep pocket," cf. Reynolds Metal Co. v. FTC, 309 F.2d 223 (D.C. Cir. 1962), or by threats of predatory pricing.

100. The Supreme Court labeled reciprocity "one of the congeries of anticompetitive practices at which the antitrust laws are aimed." FTC v. Consolidated Foods Corp., 380 U.S. 592, 594 (1965). Contrary to the Court's willingness to conclude that reciprocity has no beneficial aspects, see Ferguson, Tying Arrangements and Reciprocity: An Economic Analysis, 30 LAW \& CoNTEMP. Prob. 552, 569 (1965).

101. Stocking, Workable Compettrion and ANTITrust Policy 290 (1961).

102. Compare Consolidated Foods, where the Commission found that overt reciprocity was only sporadically used, 62 F.T.C. at 955,958 , with United States v. General Dynamics Corp., 258 F. Supp. 36, $42-44$ (S.D.N.Y. 1966), where the court found that the reciprocity power was systematically exercised through a "Special Sales Program."

The devastating effect of a well-conceived reciprocity program was evidenced in a case brought by the Commission under section 5 of the Federal Trade Commission Act, Waugh Equip. Co., 15 F.T.C. 232 (1931). The program raised the firm's share of draft gears from one percent to 35 percent in six years.

103. Ferguson, supra note 100, at 568-69. See Handler, Emerging Antitrust Issues: Reciprocity, Diversification and Joint Ventures, 49 VA. L. REv. 433, 436, 437 (1963); NaRVer, Conglomerate Mergers and Market Compettmon 100 (1967).

104. Cf. Handler, supra note 103, at 437. 
pendent determination by one firm that it might obtain more sales by purchasing froin a custoiner. ${ }^{105}$ The first form probably violates section 2 of the Sherman Act as an atteinpt to monopolize ${ }^{106}$ and certainly violates section 5 of the Federal Trade Coinmission Act as an unfair method of competition. ${ }^{107}$ The second may violate section 1 of the Sherman Act as an agreement in restraint of trade. ${ }^{108}$ The third, and clearly the fourth, are difficult to attack under other antitrust statutes. ${ }^{109}$

As a structural matter, reciprocity can exist only where one firm, $B$, both purchases from and sells to another, $A$. The relationship may be three, or even four, sided. Through its purchases from $A, B$ may induce $A$ (or a corporate subsidiary of $A$ ) to purchase from $C$ (a corporate subsidiary of $B$ ). For $B$ to be able to coerce or induce reciprocal buying, it must be the only firm, or one of the largest firms, both buying and selling; its purchases inust constitute a substantial part of $A$ 's production and $A$ 's industry must be imperfectly competitive. For the competitive inpact to be substantial the share of the market potentially subjected to reciprocity must be substantial. ${ }^{\mathbf{1 1 6}}$

The guidelines suggest that a conglomerate merger is unlawful whenever 15 percent or more of the $A$ industry purchases are accounted for by firms inaking substantial sales in the $B$ industry and where firm

105. The Commission relied heavily on the anticompetitive impact likely to result from "tacit reciprocity" in Consolidated Foods, 62 F.T.C. at 955-56. There is some question as to the competitive impact of tacit reciprocity. See Ammer, Realistic Reciprocity, 40 Harv. Bus. Rev. 116, 122 (1962).

106. See the complaint in United States v. General Tire \& Rubber Co., C 67155 (N.D. Ohio, filed Mar. 2, 1967); complaint in United States v. United States Steel Corp., 5 Trade REg. ReP. If 72,826 (W.D. Pa. 1969). It might also be attacked under the intracorporate conspiracy doctrine. See Timken Roller Bearing Co. v. United States, 341 U.S. 593 (1951) (only charged a violation of section 1); Kiefer-Stewart Co. v. Joseph E. Seagram \& Sons, Inc., 340 U.S. 211 (1951) (only section 1); United States v. Yellow Cab Co., 332 U.S. 218 (1947) (charged violations of both sections 1 and 2 ).

107. The Commission has held overt reciprocity a violation of section 5 of the FTC Act in three cases. California Packing Corp., 25 F.T.C. 379 (1937); Mechanical Manufacturing Co., 16 F.T.C. 67 (1932); Waugh Equip. Co., 15 F.T.C. 232 (1931). 108. See note 106 supra.

109. Turner, supra note 38, at 1390; see Consolidated Foods Corp., 62 F.T.C. at 956 .

110. There is considerable controversy as to what constitutes a substantial amount of commerce for this purpose. Compare FTC v. Consolidated Foods Corp., 380 U.S. 592, 600 (1965) with Turner, supra note 38, at 1391. Even where the percentage of sales theoretically subject to reciprocity pressures is substantial, additional factors may make illusory the power to coerce or induce such sales. For example, among the companies both buying dehydrated onion and garlic and selling food products through Consolidated Foods, and therefore allegedly subject to reciprocity pressures, were giants such as Heinz, Gerber and Campbell. 
$B$ purchases more than most of its competitors. ${ }^{111}$ As in vertical merger cases, conglomerate mergers resulting in reciprocity foreclose competitors from a source of sales. But unlike vertical mergers, where one firm has the absolute power to foreclose, in the reciprocity situation foreclosure depends on the reaction of firms other than the merging firms. ${ }^{112}$ Thus, the percentage of sales which must be foreclosed to bring the guideline rules into play are higher in reciprocity situationsto provide for the possibility that not all firms subject to reciprocity pressures will react to thein.

When a conglomerate inerger is attacked on grounds that it creates the opportunity for reciprocity, the defendant should be permitted to show that significant structural changes in the market have occurred which render imsubstantial the likely impact. The defendant should also be permitted to show that purchasing patterns by the firms supposedly subject to tacit reciprocity pressures indicate that the merger has not resulted in any significant alteration of pre-acquisition purchasing patterns. Only in limited situations should the failure to attempt to exercise reciprocity power created by the merger be considered.

\section{a. Failure to Attempt Overt Reciprocity}

While inquiry into the defendant's post-acquisition behavior would appear justified under Consolidated Foods, ${ }^{113}$ preoccupation with the defendant's post-acquisition implementation of or failure to implement its purported power to coerce or induce purchases is not a particularly sound basis on which to determine a conglomerate merger's illegality. The defendant may refrain froin fully employing its power to obtain purchases pending suit, but there is no assurance that it will refrain in the future.

Furthernore, it may be difficult, if not impossible, to establish whether the defendant has exercised all its reciprocity power. Indeed, to prove that it has exercised all its power without success, a defendant may be convicting itself of atteunpting to monopolize. Where the defendant can prove that it exercised fully whatever power resulted without significantly injuring competition, forcing dissolution under section 7 will gain little if anything.

In limited situations, the defendant may be able to prove that it would not attempt to engage in reciprocal buying for sound business

111. Merger Guidelines, supra note 64, at 6688 .

112. Turner, supra note 38 , at 1389.

113. All three Supreme Court opinions in Consolidated Foods appeared to rely heavily on behavioral rather than structural factors in evaluating the merger. Donnelly, supra uote 16 , at $35,66,73$. 
reasons. ${ }^{114}$ The failure to exercise reciprocity power over a prolonged post-acquisition period may provide some support. Ultimately, however, the persuasiveness of such a defense must depend on the likelihood that the busimess reasons will deter exercise in the future. Even where such a defense is persuasive as to the overt exercise of the power, the defendant still must prove that the anticompetitive effects of tacit reciprocity are marginal. The inere existence of the reciprocity power may induce firms potentially subject to the power to purchase from the defendant. The defendant's failure to attempt to coerce or induce reciprocal purchases has no probative value on this issue.

\section{b. Structural Changes}

A sounder basis for defense of a conglomerate merger creating substantial opportunities for reciprocity is proof of a post-acquisition change of one of the structural factors required for reciprocity to have substantial anticompetitive effects. For example, the firms subject to reciprocity pressures, overt or tacit, may have developed new uses for their product which reduce their reliance on the defendant's purchases. This type of showing is more persuasive for two reasons. First, it relates to the existence of an element of market structure without which reciprocity will not have a significant anticonpetitive impact. Second, it is not subject to control by the defendant.

An increase in the percentage of purcliases by the defendant's competitors in the post-acquisition period also will undermine the defendant's reciprocity power. Alternatively, the impact of reciprocity may become imsubstantial where the defendant's competitors develop alternative markets for their product in which the defendant does not have significant purchasing power.

\section{c. Purchasing Patterns}

Where a merger is alleged to be unlawful because of the likelihood that firms will favor the defendant without any action by the defendant to eniploy reciprocity, post-acquisition evidence has a definite role. The absence of changes in the buying patterns of firms accounting for a substantial part of the purchases allegedly subject to "tacit" reciprocity would be the best basis for determining probable future effects. ${ }^{110}$

114. In United States v. Penick \& Ford, Ltd., 242 F. Supp. 518 (D.N.J. 1965), tho trial court concluded that the entry of Reynolds Tobacco Company, which had a company policy against the use of reciprocity, into the starch manufacturing market by acquiring the fourth largest starch producer would tend to diminish rather than enhance the likelihood tbat reciprocity would be used. Reciprocity had been an established business practice between starch producers and their biggest customers, corrugated box and paper manufacturers.

115. It was the presence of such shifts that Justice Stewart relied on in finding Consolidated's acquisition of Gentry unlawful. 380 U.S. at 607-08 (concurring opinion). 
Such evidence reflects the reactions of those purportedly subject to reciprocity pressures and, by definition, is not subject to manipulation by the defendant.

\section{Elimination of Potential Competition}

Under the merger guidelines, the Department will challenge mergers between one of the most likely entrants into and a leading firm in an oligopoly market on the ground that they eliminate potential competition. As a potential entrant into the acquired firm's market, the acquiring firm inay have restrained actual coinpetitors froin abusing their position in the market. Alternatively, in the absence of the merger, the acquiring firm might have entered the market through internal expansion.

In determining whether a firm was a likely entrant, the guidelines suggest reliance on the potential entrant's ability to enter at a relatively efficient size and its economic incentive to do so. The plaintiff might also establish such likely entry by soine special relationship between the potential entrant's market and the market involved, manifested by an interest in entry or a history of expansion under similar circumstances.

While the guidelines fail satisfactorily to set forth the factors which reasonably can be relied on to establish that the potential entrant inight have had a substantial restraining effect on firms in the market, FTC v. Proctor \& Gamble Company ${ }^{116}$ casts light on the likely approach. In that case the Supreme Court referred to four facts in concluding "that the existence of Proctor at the edge of the industry exerted considerable influence on the market."117 First, from the fact that the industry was oligopolistic, the Court concluded that liquid bleach producers were influenced by their assessment of the likely behavior of their actual and potential competitors. Second, barriers to entry by a firm like Proctor were not significant. Third, the number of potential entrants was not so large that elimination of one would be insignificant. Fourth, Proctor was the most likely entrant.

For the potential competition theory to apply, actual competitors must assess the likely response of the potential entrant to their competitive conduct. There is simply no support for the proposition that olgopolists invariably consider potential entrants in setting price, style or the like. Many oligopolies are highly competitive markets, particularly those in which a number of small firms have been able to compete successfully over a period of years. ${ }^{118}$ This fundamental weakness in the theory of illegality must be borne in inind in analyzing the propriety

116. 386 U.S. 568 (1967).

117. Id. at 581 .

118. See J. BaIN, Price Theory 301 (1952). Professor Bain also explains the 
of defensive reliance on post-acquisition evidence of entry or changed pricing patterns.

\section{a. Post-acquisition Entry}

Post-acquisition evidence is virtually useless in determining whether the acquiring firm would have entered the market by internal expansion if it had not entered by merger. The absence of new entrants after the merger has a reinote bearing, at best, on the probability that the acquiring firm would have entered. Successful entry by one or several firms after inerger might, however, support the conclusion that the new entrants have more than filled the role the acquiring firm would have played had it entered on its own. More important, such entry tends to negate the arguinent that the merging firm was one of the few likely entrants.

Where the market is a tight oligopoly and where the potential entrant was substantially larger than the leading firms in the market, postacquisition entry should not be accorded significant weight. In this situation, the existence of even one additional firm may be important in ensuring a workably competitive inarket. The mere size disparity between a large conglomerate and another new entrant will not dictate that the conglomerate will be the unore successful competitor. The conglomerate's greater resources nay, however, permit it to challenge the leading firms in the industry successfully.

\section{b. Pricing Patterns}

To determine whether the acquiring firm's presence as a potential competitor had a restraining effect, the most direct evidence would be testimony by actual competitors. Alternatively, the industry pricing pattern before and after the merger might be compared. Inquiry along these lines would expand the litigation substantially and may be equivocal due to a large number of factors which may influence pricing patterns. But since the basic theory of illegality is weak, the court should permit the defendant to atteinpt to establish its case on this issue unless the market involved is a tight oligopoly.

Even where such inquiry is permitted, the court should limit it to a few factors, such as coinparison of price patterns in the face of particular market situations. For example, if the acquiring firm as a potential competitor had a restraining effect on abuse of pricing power, actual coinpetitors may have reframed from raising prices in the face of increasing costs or demand. ${ }^{119}$ When such a pattern is established by

factors which may lead to vigorous competition in oligopoly markets despite the obvious mutual interest in maximizing joint profits. Id. at 276-79.

119. Turner, supra note 38 , at 1375-76. 
pre-acquisition evidence, post-acquisition evidence of a similar reaction would tend to negate the conclusion that the acquiring firm's disappearance is likely to have a substantial anticompetitive effect. If the firms in the market continued to absorb increased costs or keep prices down in the face of rising demand, the loss of the acquiring firm from the fringe would appear insignificant. This type of evidence is beyond the defendant's control and shows concretely how the market operates and is likely to continue operating.

\section{Entrenchment of Existing Market Power}

A large conglomerate's acquisition of a leading firm in an industry of firms significantly smaller than the new entrant may make the smaller firms more timid in wagnig price competition. In addition, the presence of a disproportionately large, diversified firm might deter new entry into the market. The very existence of the power to sustain below cost pricing, as the mere existence of the power to cause reciprocal buying, may restrict competition without its exercise. Apprehension by the smaller actual or potential competitors may make overt exercise of power unnecessary.

The most direct evidence of any such restraining effect would be the response by competitors to the merger. If firms are going to be intimidated by a conglomerate's intrusion into the market, their less competitive actions should become apparent in a relatively short period of time. An absence of a significant change in the competitive efforts by smaller firms, the pattern of pricing in inarkets, the failure of the smaller firms to atteinpt to merge with a large firm, ${ }^{120}$ or an undiminished flow of efficiently sized entrants within a year or two after the merger should be sufficient to rebut the theoretical argument.

There is no way to determine whether other firms might not have entered or whether price competition would have been more vigorous in the absence of the merger. But unless the Government can show some reason why entry or price competition should have been greater, to conclude that the structure of the inarket has changed in such a way that anticompetitive effects are likely to develop is to rely on presumptions unsupported by facts.

\section{CONCLUSION}

Notwithstanding the prospective test set out in section 7 of the

120. Indeed, the likelihood that firms threatened by foreclosure or predatory pricing resulting from the merger would seek to protect themselves by merging as a defensive measure is one of the theories used to attack vertical or conglomerate mergers. See, e.g., United States v. Kimberly-Clark Corp., 264 F. Supp. 439, 447 (N.D. Cal. 1967). 
Clayton Act, proof of what actually occurs after a merger, where such evidence is available, can be a useful tool not only to defendants in preparing their case, but also to the enforcement agencies in determining whether to attack a merger and to the courts in rendering a judgment. Mergers are not unlawful per se. The tendency toward the development of rules of presumptive illegality based on economic theory should never be permitted to obscure the fundamental fact that the underlying theory must function in the real world.

In many situations careful analysis of post-acquisition evidence will indicate that the predictions of economic theory are unsound. At a minimum, courts should allow the introduction of post-acquisition evidence to prove that the factors which existed at the time of merger, and which call the presumptive rules into play, no longer exist. In cases where the basic presumptive rules are less compelling, whether because of lack of support from empirical studies or of weaknesses in the theory, the courts should allow more latitude in developing defenses based on post-acquisition evidence.

All post-acquisition evidence should meet three tests: It should not be subject to control by defendants; it should be directed ultimately to proof of changes in the structure of the market; and a stringent test of relevancy should be applied to prevent the court and the parties from becoming involved in a hopeless morass of facts and statistics. Ultimately, the success of a particular defense based on post-acquisition evidence will turn on whether the defense establishes that the merger has not offended nor is likely to offend the fundamental policies on which the rules of presumptive illegality are based."

* In a case reported as this issue goes to press, Metropolitan Liquor Co. v. Heublein, Inc., 305 F. Supp. 946 (E.D. Wis. 1969), the district court lield that the statute of limitations does not begin to run on a private treble damage action based on section 7 of the Clayton Act until the plaintiff is injured.

The decisions upholding the propriety of private treble damage actions based on section 7 at most state that the plaintiff must prove a violation of section 7 and his injury resulting therefrom. See, e.g., Gottesman v. General Motors Corp., 414 F.2d 956 (2d Cir. 1969). They do not specify, for example, the time at which the merger's illegality must be proven. Presumably, the violation and the injury would have to coincide or the requisite causation would be absent. Thus, defendants undoubtedly will seek to introduce fundameutally the same evidence in private actions that they have endeavored to introduce in government litigation. In addition, post-acquisition evidence clearly will be relevant to the issue whether the plaintiff actually lias been injured by the merger. 


\title{
California Law Review
}

VoL. 58

JANUARY 1970

No. 1

\section{BOARD OF EDITORS}

\author{
Editor-in-Chief \\ H. Lee VAN Boven \\ Managing \\ THORNTON E. ROBISON \\ WALTER I. CarPenetI \\ A. TERRY SLOCUM \\ Articles \\ DeRER A. Westen \\ Research \\ PAUL HOEBER \\ GlenN C. Frese \\ VINCENT L. RICCI \\ Book Reviews \\ ROBERT G. WERNER
}

Notes \& Comments

PETER N. SimoN

JAMES W. BROWN

MARY LU EVERETT

LESLIE S. KLINGER

Marietta PoErio

ErIC R. Roost

WENDY Williams

Executive Editor

JEFFREY R. FREUND

Steven M. AldeN

Steven Finell Ellyn A. HeRshman

PETER J. AsCHENBRENNER

FrANK D. BERRY

WILLIAM BILIINGSLEA, JR.

MERRICK JOHN BOBB

J. MICHAEL BRENNAN

William M. Chamberlain

Howard D. COLEMAN

WIILIAM FREDERICK COOK

G. KIP EDWARDS

Gordon KIRK Ellis

ROBERT D. EVANS

GREGORY J. HoBBS, JR.

Charles H. Hurd

JOSEPH T. KIEFER

JEFF KINGSTON

DARUISH M. KoRdestant

Michael George Kozar

Douglas M. LaUrice

ROBERT LEVY

RICHARD FRASER LYON

Administrative Aide

SusAN G. Vega
Robin MEAdow

Michael L. Meyers

Douglas Alan Oglesby

Richard L. PEReZ

Bruce S. Ross

KENT A. RusSELI

Peter E. Sheehan

Kent Sinclatr

DOUGLas Sykes

MARIA TANKENSON

JAMES TOLEDANO 